\title{
STRATEGI KOMUNIKASI PEMASARAN OBJEK WISATA GOA LAUK DI KABUPATEN LEBAK, BANTEN
}

\author{
Lukman Saleh Waluyo' \\ Irpan Ripa'i Sutowo' \\ 1,2Program Studi IImu Komunikasi, UPN Veteran Jakarta
}

Naskah diterima tanggal 01-12-2020, direvisi tanggal 31-01-2021, disetujui tanggal 02-02-2021

\begin{abstract}
Abstrak. Goa Lauk adalah Goa yang teletak di Desa Lebaktipar, kecamatan Cilograng kabupaten Lebak. Goa ini merupakan Goa yang memiliki ukuran besar dengan bentuk Goa bawah tanah yang dialiri oleh sungai bawah tanah yang berasal dari sungai sawarna. Goa ini telah lama menjadi bahan penelitian baik dari kalangan akademisi maupun ilmuwan, karena goa ini memiliki keunikan dan tekstur yang sangat indah, mulai dari keadaan alamnya, karang-karangnya dan segala ornamen yang terdapat di dalam goa tersebut. Tujuan dari penelitian ini adalah untuk mengetahui bagaimana strategi komunikasi pemasaran Objek Wisata Goa Lauk dan untuk mengetahui bagaimana dampak komunikasi pembangunan setelah adanya Objek Wisata Goa Lauk. Metode yang digunakan di dalam penelitian ini adalah metode deskriptif dengan pendekatan kualitatif. Hasil penelitian diperoleh bahwa kegiatan komunikasi pemasaran yang dilakukan oleh pengelola Goa Lauk sudah banyak diupayakan, namun hal tersebut belum cukup untuk mengangkat citra Goa Lauk. Pengelola menghadapi masalah utama yaitu tentang ketersediaan sumberdaya manusia dan permodalan, dimana hal tersebut sebetulnya dapat diatasi dengan alternatif-alternatif kreatif yang dapat digunakan. Goa Lauk mempunyai potensi besar untuk wisata karena sumber daya alam yang tidak banyak dimiliki di tempat lain, namun butuh upaya serius untuk mempromosikan hal tersebut. Strategi komunikasi pemasaran yang perlu ditingkatkan dengan strategi zero budget marketing.
\end{abstract}

Kata kunci: Goa Lauk, komunikasi pemasaran, strategi zero budget marketing

Abstract. Goa Lauk is a cave located in Lebaktipar Village, Cilograng District, Lebak Regency. This cave is a cave that has a large size in the form of an underground cave which is fed by an underground river originating from the Sawarna river. This cave has long been the material of research both from academics and scientists, because this cave has a unique and very beautiful texture, starting from its natural state, the corals and all the ornaments contained in the cave. The purpose of this study is to determine how the marketing communication strategy of Goa Lauk Tourism Object and to find out how the impact of development communication after the existence of Goa Lauk Tourism Object. The method used in this research is descriptive method with a qualitative approach. The results showed that the marketing communication activities carried out by the manager of Goa Lauk have been made a lot of efforts, but this is not enough to raise the image of Goa Lauk. Managers face the main problem, namely regarding the availability of human resources and capital, where this can actually be overcome with creative alternatives that can be used. Goa Lauk has great potential for tourism due to natural resources that are not widely available elsewhere, but it takes serious efforts to promote it. Marketing communication strategy that needs to be improved with a zero budget marketing strategy.

Keywords: Goa Lauk, marketing communications, zero budget marketing strategy 


\section{PENDAHULUAN}

"Goa Lauk" adalah Goa yang teletak di Desa Lebaktipar, kecamatan Cilograng kabupaten Lebak. Goa ini merupakan Goa yang memiliki ukuran besar dengan bentuk Goa bawah tanah yang dialiri oleh sungai bawah tanah yang berasal dari sungai sawarna. Goa ini telah lama menjadi bahan penelitian baik dari kalangan akademisi maupun ilmuwan, karena goa ini memiliki keunikan dan tekstur yang sangat indah, mulai dari keadaan alamnya, karang-karangnya dan segala ornamen yang terdapat di dalam goa tersebut. Oleh karena itu menarik untuk meneliti bagaimana strategi komunikasi pemasaran digital Bumdes pengelola objek wisata Goa Lauk.

Komunikasi pemasaran adalah sarana di mana perusahaan berusaha menginformasikan, membujuk, dan mengingatkan konsumen secara langsung maupun tidak langsung tentang produk dan merek yang dijual. Komunikasi pemasaran mempresentasikan "suara" perusahaan dan mereknya serta merupakan sarana di mana perusahaan dapat membuat dialog dan membangun hubungan dengan konsumen.

Komunikasi pemasaran juga digunakan dalam dunia bisnis untuk mempertahankan produk dengan basis konsumen, dan untuk membangun hubungan antara konsumen dan penyuplai atau pemasok. Strategi komunikasi pemasaran diartikan sebagai perencanaan bisnis melakukan penyebaran informasi produk dan pengembangan brand awareness. Komunikasi pemasaran terdiri dari 2 (dua) elemen penting, yaitu komunikasi dan pemasaran. Secara umum, komunikasi adalah proses penyampaian pesan yang dilakukan oleh komunikator atau pengirim pesan kepada komunikan atau penerima pesan melalui saluran tertentu untuk mempengaruhi sisi kognitif, afektif, dan psikomotor penerima pesan. Philip Kotler dan Kevin Lane Keller dalam bukunya Marketing Management (2016) menyatakan bahwa : "Marketing is about identifying and meeting human and social needs". Menurut definisi tersebut, pemasaran adalah mengidentifikasi dan memenuhi kebutuhan manusia dan kebutuhan sosial. Sementara itu, menurut The American Marketing Association, yang dimaksud dengan pemasaran adalah: "....is the activity, set of institutions, and processes for creating, communicating, delivering, and exchanging offerings that have value for customers, clients, partners, and society at large". Pemasaran adalah kegiatan, sekumpulan perintah, dan serangkaian proses membentuk, mengkomunikasikan, mengirim, dan menukarkan penawaran yang bernilai kepada konsumen, klien, rekanan, dan masyarakat pada umumnya (Kotler dan Keller, 2016).

Komunikasi pemasaran bagi konsumen, dapat memberitahu atau memperlihatkan kepada konsumen tentang bagaimana dan mengapa suatu produk digunakan, oleh orang macam apa, serta di mana dan kapan. Komunikasi pemasaran berkontribusi pada ekuitas merek dengan menanamkan merek dalam ingatan dan menciptakan citra merek serta mendorong penjualan dan bahkan mempengaruhi nilai pemegang saham.

Kelompok rujukan adalah kelompok yang digunakan sebagai alat ukur atau standar untuk menilai diri sendiri atau untuk membentuk sikap (Rakhmat, 2001). Dalam kaitannya dengan komunikasi pemasaran, yang dimaksud dengan kelompok rujukan adalah kelompok dimana seseorang menerima sebagai sebuah kerangka rujukan yang digunakan untuk evaluasi diri dan pembentukan sikap (Kayode, 2014). Lebih lanjut Kayode menyatakan bahwa terdapat tiga tipe kelompok referensi, yaitu keanggotaan (membership), kelompok pendahulu (anticipatory), dan kelompok disosiasi (dissociative).

1. Kelompok rujukan keanggotaan (membership reference group) adalah kelompok rujukan dimana seorang individu secara otomatis berada karena beberapa factor seperti kelahiran, jenis kelamin, ras, pendapatan, status pernikahan, dan usia.

2. Kelompok aspirasi keanggotaan (anticipatory membership reference group) adalah kelompok rujukan dimana seorang individu ingin berada.

3. Kelompok disosiasi (dissociative reference group) adalah kelompok rujukan dimana seorang individu tidak berkeinginan untuk berada didalamnya.

Selain kelompok rujukan, keluarga juga dapat mempengaruhi seseorang untuk memilih atau membeli produk. Menurut Dwiastuti dkk dalam bukunya IImu Perilaku Konsumen (2012) 
menyatakan bahwa setiap anggota keluarga dapat berperan dalam pengambilan keputusan pembelian, peran tersebut adalah :

1. Inisiator - setiap anggota keluarga mempunyai ide atau gagasan untuk membeli produk.

2. Pemberi pengaruh - setiap anggota keluarga dapat memberikan informasi bagi anggota keluarga yang lainnya mengenai suatu produk.

3. Penjaga pintu - setiap informasi yang masuk ke dalam keluarga disaring oleh anggota keluarga yang lain

4. Pengambil keputusan - setiap anggota keluarga memiliki kekuasaan untuk membuat keputusan membeli atau tidak suatu produk atau jasa.

5. Pembeli - setiap anggota keluarga yang akan membeli suatu produk atau jasa.

6. Pengguna - setiap anggota keluarga yang akan menggunakan suatu produk atau jasa.

7. Pembuang - setiap anggota keluarga dapat membuang suatu produk atau jasa.

Dari berbagai studi menunjukkan bahwa pengambilan keputusan yang dilakukan oleh keluarga mengenai suatu produk lebih didominasi oleh istri. Sedangkan suami hanya dominan dalam pengambilan keputusan. Selain itu, ada juga pengambilan keputusan yang tidak tergantung satu sama lain dan keputusan yang diambil dilakukan secara bersama-sama.

Market segmentation is the process of dividing the total heterogeneous market for a product into several sub market or segment, each of which tends to be homogenous in all significant aspects (Kayode, 2014). Segmentasi pasar adalah proses membagi pasar yang seluruhnya heterogen untuk produk menjadi beberapa sub pasar atau segmen, yang masingmasing cenderung homogen dalam segala aspek yang signifikan. Terdapat 3 teknik segmentasi pasar, yaitu :

1. Demografis - teknik segmentasi pasar yang didasarkan pada aspek demografis, seperti usia, jenis kelamin, ukuran keluarga, tahapan dalam lingkaran kehidupan keluarga, pendapatan, okupasi dan faktor-faktor lainnya.

2. Geo-demografis - teknik segmentasi pasar yang didasarkan pada tempat dimana ia tinggal.

3. Psikografis - teknik segmentasi pasar yang mengelompokkan khalayak berdasarkan nilainilai, ciri-ciri kepribadian, minat, dan lain-lain.

Dalam melakukan segmentasi pasar, terdapat beberapa prosedur yang harus dilalui yaitu

1. Analyzing consumer product realtionships - menganalisis hubungan produk konsumen.

2. Investigating segmentation bases - menginvestigasi dasar-dasar segmentasi.

3. Developing product positioning - mengembangkan positioning produk.

4. Selecting segmentation strategy - memilih strategi segmentasi.

5. Designing marketing mix strategy - merancang strategi bauran pemasaran.

Strategi pada hakekatnya adalah perencanaan dan manajemen untuk mencapai tujuan. Strategi komunikasi merupakan paduan perencanaan komunikasi dengan manajemen komunikasi untuk mencapai tujuan yang telah ditetapkan. Pada komunikasi pemasaran, strategi komunikasi pemasaran adalah panduan perencanaan komunikasi pemasaran dengan manajemen komunkasi pemasaran untuk mencapai tujuan yang telah ditetapkan. Dalam komunikasi pemasaran, strategi komunkasi dikenal dengan komunikasi pemasaran terpadu.

Komunikasi pemasaran terpadu adalah suatu strategi, dua tahap komunikasi yang ditujukan kepada konsumen khusus dan pemenuhan kebutuhan mereka yang dikoordinasikan melalui beragam media. Dalam menyusun strategi komunikasi pemasaran diperlukan suatu pemikiran yang memperhitungkan berbagai faktor pendukung dan faktor penghambat. Harus diperhatikan pula komponen-komponen komunikasi pemasaran yang disertai dengan berbagai faktor pendukung dan penghambat dari masing-masing komponen komunikasi pemasaran. Secara sederhana, tahapan proses perencanaan strategi komunikasi pemasaran terpadu meliputi beberapa tahap, yaitu :

1. Menetapkan tujuan komunikasi. 
2. Menentukan peran masing-masing media.

3. Menyusun pesan

4. Menempatkan pesan pada media yang sesuai

5. Hasil pesan

6. Membuat penyesuaian dalam pesan atau media

\section{METODE PENELITIAN}

Metode penelitian pada dasarnya merupakan sebuah cara ilmiah untuk mendapatkan data dengan tujuan dan kegunaan tertentu (Sugiyono, 2013). Metode yang digunakan di dalam penelitian ini adalah metode deskriptif dengan pendekatan kualitatif. Penelitian kualitatif merupakan penelitian yang lebih mengutamakan pada masalah proses dan makna, di mana penelitian ini diharapkan dapat mengungkap berbagai informasi kualitatif dengan deskripsi analisis yang teliti dan penuh makna (Muhadjir, 1996). Peneliti menggunakan metode ini sebab ingin mencari tahu bagaimana strategi komunikasi Objek Wisata Goa Lauk.

Di dalam penelitian ini peneliti mengamati keadaan yang sebenarnya yang terjadi di lapangan. Peneliti akan melakukan wawancara mendalam untuk mengumpulkan informasi secara terperinci mengenai strategi komunikasi Objek Wisata Goa Lauk.

\section{Gambaran Subjek Penelitian}

\section{HASIL DAN PEMBAHASAN}

Subjek dalam penelitian ini adalah orang-orang yang memiliki berbagai informasi dan terlibat secara langsung dalam interaksi sosial yang diteliti sehingga dapat diperoleh data yang digunakan untuk menjawab rumusan masalah penelitian. Dalam penelitian ini yang menjadi subyek penelitian adalah para pengurus Bumdes Cipta daya Gemilang yang mengelola objek wisata Goa Lauk.

Tabel 1. Subjek Informan Kunci

\begin{tabular}{|c|l|l|}
\hline No & \multicolumn{1}{|c|}{ Subjek Penelitian } & \multicolumn{1}{c|}{ Latar Belakang } \\
\hline 1. & Maman & Pembina Bumdes \\
\hline 2. & Ujang Tarkim & Anggota Bumdes \\
\hline 3. & Jaro Yayat & Jaro / Lurah Ds. Lebaktipar \\
\hline 4. & Lukky Lukman Rakhim & Direktur Bumdes \\
\hline
\end{tabular}

\section{Tentang Objek Penelitian Goa Lauk}

Bumdes Cipta Daya Gemilang mempunyai 2 unit usaha yang pertama adalah Delta Mart (Desa Lebaktipar Mart). Yang kedua adalah wisata edukasi Goa Lauk. Delta Mart belum sebanding dengan Alfamart atau Indomaret, begitu juga dengan Goa Lauk belum sebanding dengan Sawarna yang sudah jauh lebih dulu muncul. Dan juga Goa Lauk adalah Goa dimana tidak semua orang suka ke Goa, beda dengan pantai yang lebih umum. Apalagi sekarang sedang pandemi Corona sehingga pengunjungnya sedikit. Walaupun sebelumnya sudah ada pengunjung yang memang khusus mencari tantangan, bahkan dari luar negeri. Untuk guide dan keamanan sudah ada, beserta alat keselamatan seperti helm dan sepatu boot.

Sebagian besar mata pencaharian warga desa Lebaktipar adalah petani atau guru. Karena orang yang pertama sekali sekolah di daerah situ adalah orang pendidikan. Di wilayah Desa Lebaktipar termasuk Goa Lauk banyak batu yang bernilai tinggi yang digunakan sebagai inti semen, oleh karena itu sudah banyak tanah yang dikuasai oleh PT Semen Indonesia. Dan dibeli dengan harga murah karena tidak tahu bahwa bahan inti semen yaitu pasir kuarsa atau batu gamping itu bernilai tinggi. Oleh karena itu Goa Lauk dibuka dengan tujuan utama adalah menyelamatkan lingkungan, karena jika tidak diurus maka bisa diambil oleh PT dan dikeruk isinya. Pak Maman dan teman-teman mengetahui hal tersebut dari teman-teman di berbagai perguruan tinggi. Jadi tujuan utama pembagunan objek wisata Goa Lauk bukanlah untuk wisata, 
namun lebih ke pelestarian lingkungan. Pariwisata merupakan bonus. Ada tujuan jangka pendek, jangka menengah, dan jangka panjang.

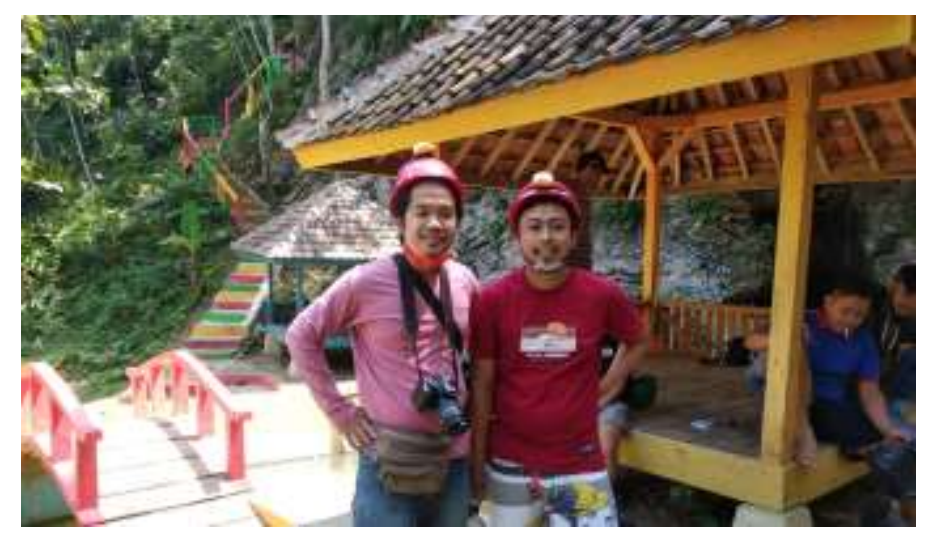

Gambar 1. Peralatan Keselamatan Wisata Goa Lauk

Tujuan jangka pendek adalah membuka jalan juga untuk mengambil hasil alam di kebun, karena jika tidak ada jalan maka biaya operasional menjadi tinggi. Kalau tidak ada jalan tidak bisa mengambil hasil alam seperti kelapa, pisang, dengan menggunakan motor, sehingga biaya operasional menjadi tinggi jika manual menggunakan orang. Target jangka menengah adalah untuk mendapat tambahan pemasukan desa dengan membuka objek wisata walaupun sampai sekarang belum terlalu menghasilkan. Target jangka panjang adalah ingin menyelamatkan lingkungan atau konservasi alam. Oleh karena itu wisata Goa Lauk adalah wisata edukasi, bukan wisata seperti tempat lain dimana mengundang sebanyak-banyaknya orang.

"Sebagian besar lahan sudah dikuasai oleh pihak ketiga yg bergerak dibidang tambang semen. Tujuan utama menjaga melestarikan ekosistem alam, Karena sebagian besar lahan sudah dikuasai pihak ketiga, hanya tinggal menunggu waktu dieksploitasi oleh semen merah putih, lokasi pabrik di bayah. Pihak desa serius ingin menjaga lingkungan dibantu pihak-pihak lain, seperti akademisi, dll." - Subyek Jaro Yayat

"Beberapa pihak sudah mengunjungi goa disini, dan disarankan dijadikan laboratorium kajian atau membuat museum kecil-kecilan tentang goa karena kebanyakan pengunjung dari akademisi. dulu batuan ini diambil bebas oleh warga, berdasarkan info dr geologi batuan ini tumbuh $1 \mathrm{~cm}$ butuh waktu 400 tahun" - Subyek Jaro Yayat

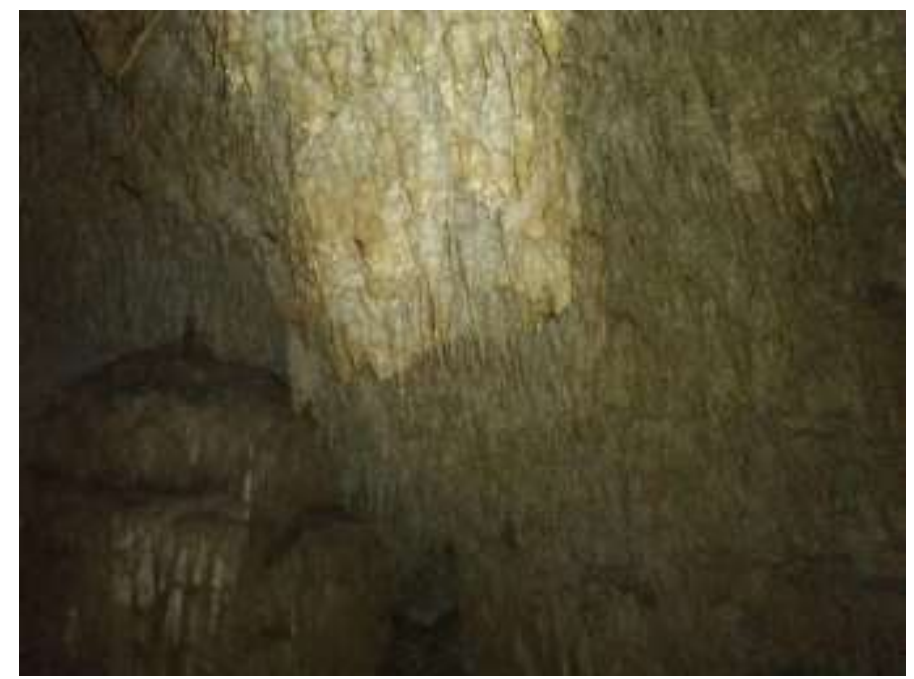

Gambar 2. Batuan Gamping yang dimiliki Goa Lauk 
Wisata edukasi Goa Lauk lebih dikhususkan untuk belajar oleh karena itu sering mengundang ke sekolah atau kampus untuk datang, dan dibatasi jumlah pengunjung yang datang dalam satu waktunya, selain karena memang oksigen di dalam gua terbatas, namun juga agar kondisi kelestarian alamnya tetap terjaga. Beda dengan ancol atau sawarna, jadi wisata pendidikan bukan wisata hura-hura. Dan di Kabupaten Lebak hanya Goa Lauk yang wisata edukasi, wisata goa di daerah lain tidak ada yang seperti itu. Batuan gamping yang ada di Goa Lauk bisa menyimpan air, oleh karena itu harus diselamatkan. Batuan tersebut merupakan batuan yang dapat tumbuh dimana setahun tumbuh hanya $0,2 \mathrm{ml}$, sehingga apat disimpulkan batu disana sudaha dayang 5 meter jadi sudah terbentuk sangat lama, bisa ribuan tahun. Oleh karena itu mesti diselamatkan.

"Goa Lauk sudah telusuri dan diteliti oleh mahasiswa geodesi Universitas Pakuan bogor, hasil kajiannya adalah Goa Lauk memiliki bentangan batuan gamping kelas satu, dengan bukti2 yang masih tersisa" - Subyek Jaro Yayat

"dijadikan wisata goa lauk hanya untuk sambilan saja, utamanya untuk melestarikan lingkungan. diharapkan pengelolaan wisata yg ideal yaitu wisata berjalan baik, namun lingkungan tetap terjaga. Penataan wisata goa lauk tujuan utama untuk menyelamatkan lingkungan, sehingga jenis wisata yg ingin dibangun adalah wisata edukasi, seperti lokasi penelitian, pendidikan anak sekolah, berdasarkan hasil penelitian dan khawatir pihak ketiga PT Gama (pabrik semen) merambah eksploitasi alam lebih luas. wisata edukasi, bukan wisata sebanyak2nya datang, dirasa jika ada waiting list pengunjung akan menjadi daya tarik sendiri, karena dibatasi jumlah pengunjung" - Subyek Jaro Yayat

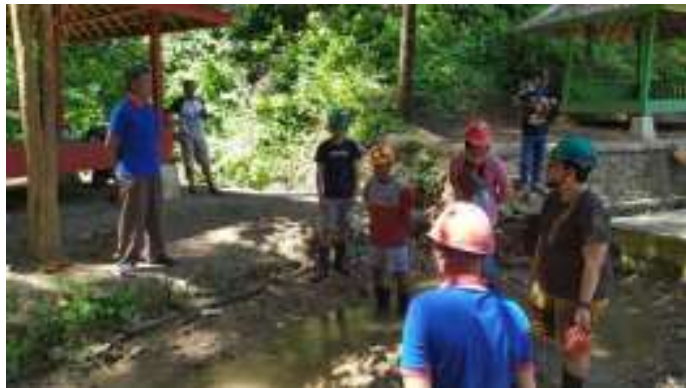

\section{Gambar 3. Pengarahan Sebelum Masuk Wisata Goa Lauk oleh Tour Guide}

Goa Lauk terdiri dari dua bagian atas dan bawah, yang bawah terdiri dari aliran sungai sepanjang kurang lebih $2 \mathrm{~km}$. Yang bagian atas karena kering relatif aman, anak kecil bisa masuk. Untuk menjelajahi Goa Lauk kurang lebih membutuhkan waktu 4 jam, dan harus membawa perbekalan seperti makanan, senter, air minum, dll.

"Goa Lauk lorong utamanya berukuran 1.822 m, percabangan 5, butuh waktu 5-6 jam untuk menelusuri goa lauk, oksigen cukup, rekomendasi maksimal 80 orang pengunjung di dalam. akses masuk goa lauk ada dua, satu di atas bersifat lahan kering ada icon buntut ikan disediakan tangga dan fasilitas yg baik agar wisata banyak berkunjung sebentar 30-60 menit untuk foto-foto dan dibawah yg tergenang air untuk penghobi utamanya" - Subyek Jaro Yayat

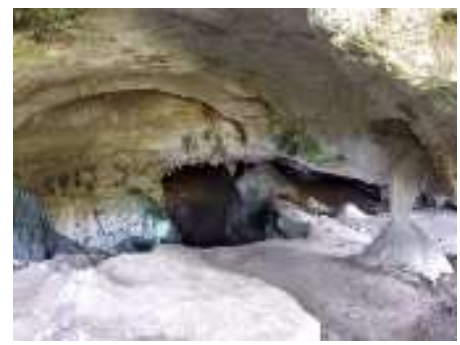

Gambar 4. Bagian Atas Wisata Goa Lauk 


\section{Kegiatan Komunikasi Pemasaran Goa Lauk}

Goa Lauk dijadikan tempat wisata pada tahun 2018. Yang rutin mengunjungi Goa Lauk sebanyak ini adalah anak sekolah, dimana mereka tahu informasi tentang Goa Lauk dar media sosial seperti Facebook dan Youtube. Dan sudah mengundang media seperti TV Banten. Koran juga sudah pernah meliput Goa Lauk karena narasumber kebetulan banyak jaringan ke media cetak koran. Radio pun seperti itu, juga pernah dipanggil. Pesan yang disampaikan melalui media tersebut adalah "wisata edukasi." Dan justru dari media tersebut juga mendukung konsep tersebut karena jika wisata umum cenderung akan merusak lingkungan. Dan yang datang juga sudah cocok karena kebanyakan adalah anak sekolah dan kuliah bukan turis umum yang merusak lingkungan.

"Wisata edukasi, bukan wisata sebanyak-banyaknya datang, dirasa jika ada waiting list pengunjung akan menjadi daya tarik sendiri, karena dibatasi jumlah pengunjung" - Subyek Jaro Yayat

Jika menggunakan media lini atas seperti TV, radio, dan koran sudah dipakai, namun media lini bawah seperti acara event belum pernah dilakukan. Jika ingin dilakukan maka konsepnya adat, adat bayah karena di Banten mempunyai adat kasepuhan bayah. Karena Goa Lauk masuk ke dalam wilayah tersebut. Jadi seperti itu konsep yang diinginkan untuk media below the line namun belum terlaksana. Festival adat tersebut seperti syukuran dengan membawa hasil bumi. Mengapa adat karena Goa Lauk merupakan tempat pertemuan para leluhur yang ada di wilayah Banten kidul seperti Nyi Roro Kidul, Roro Anteng, tempat pertemuan secara spiritual. Jadi Goa Lauk bukan hanya tentang alam tapi juga spiritual, dan berencana dibuka wisata Religi yaitu Ziarah ke Cadas Ngampar.

"Budaya-budaya yang dulu sudah terkikis tapi akan dibangkitkan lagi, seperti adat kesepuhan yg sudah mulai dibangkitkan, di undang-undang desa ada desa adat yang diangkat lagi, yaitu dari sisi pemeliharaan lingkungan, biasanya adat kesepuhan menjaga lingkungan lebih bagus, misal seresesi berat apapun kesepuluh tidak terdampak sama sekali karena ada lumbung padi, dan ada pengaturan sistem tani bersama, saat ini sering terjadi gagal panen semenjak lunturnya budaya atau kasepuhan (tidak satu komando kesepuhan lagi)" - Subyek Jaro Yayat

Untuk media digital Goa Lauk mempunyai akun khusus yang dibuat oleh pengurus yang berusia lebih muda, di platform YouTube dan Facebook, yang berisi lebih kepada menonjolkan gambar dan jenis-jenis batuan yang ada di sana, yaitu batuan stalaknit. Dan batuan tersebut tidak ada di Goa lain menurut akademisi yang sudah meneliti ke sana, walaupun Goa di desa cilograng banyak, namun tidak ada stalaktitnya sehingga bisa disebut sebagai Geopark atau konservasi alam, karena banyak juga habitat hewan-hewan yang ada di sana. Jadi website belum digunakan.

"Kabupaten lebak mendorong untuk membuat Geopark Bayah Zone, dari bentangan malimping Bayah, untuk wilayah desa ini terdapat hamparan batu gamping kelas satu dan harus dilindungi sesuai arahan ESDM, tetapi masih butuh kajian dari berbagai pihak. Batuanbatuan vertikal ada, menunggu komunitas panjat tebing mengunjungi

"- Subyek Jaro Yayat

"Desa Lebak Tipar memiliki 8 Goa, yg memiliki potensi untuk wisata ada 4, diantaranya yaitu goa lauk, dan Goa Panyumputan" - Subyek Jaro Yayat

Menurut Pak Maman, ke depan Goa Lauk idak ingin seperti sawarna yang sangat terbuka, karena takut lingkungannya rusak, karena lebih fokus pada wisata edukasi. Saat ini harga tiket Goa Laukmadalah 5.000 bagi yang masuk ke depan pintu Goa, namun bagi yang masuk lebih ke 
dalam maka diminta lagi biaya namun belum ditentukan. Saa ini fasilitas di Goa Lauk masih terbatas seperti belum ada MCK dan Mushola, baru ada Gazebo dan Pos Tiket.

"Tiket masuk Goa Lauk sudah ada, buku pengunjung tidak ada. Tiket zona 1 (350m) 15.000 (tips guide), tiket 5 ribu, dengan fasilitas peralatan safety seperti head lamp, boot, sedangkan zona 22 km" - Subyek Jaro Yayat

Anggaran yang didapat dari pemerintah rencananya digunakan untuk membuat fasilitas dan promosi. Namun belum ada rincian anggaran promosi untuk apa digunakan detilnya. Sebelumnya promosi di media koran tidak ada khusus, hanya sekedar uang bensin atau tips. Karena juga mengundang media tersebut berdasarkan unsur pertemanan juga.

"Pemasaran yg sifatnya formal blm ada, karena fasilitas kurang memadai, seperti MCK, namun karena covid pembangunan terhambat yg seharusnya terbangun tahun ini” - Subyek Jaro Yayat

Menarik karena wisata edukasi dibatasi pengunjungnya maka ada korelasi terhadap biaya pemeliharaan. Media ingin datang meliput juga karena ada batuan yang menarik di Goa Lauk, yang termasuk ke dalam kegiatan Public Relation \& Publicity. Saat ini juga Goa Lauk juga belum pernah melakukan direct marketing atau personal selling ke target audience seperti sekolahsekolah, karena SDM dan dana belum mendukung. Karena baru-baru ini juga Goa Lauk membentuk PokDarWis atau Kelompok Sadar Wisata dari anak karang taruna sebagai SDM.

"Sebelumnya Goa Lauk hanya dikelola oleh Bumdes sekarang dibantu oleh karang taruna" - Subyek Lukky

Namun ada masalah juga karena belum ada kejelasan tentang dana bagi mereka. Jadi mereka sebetulnya ingin melakukan kegiatan tersebut jika fasilitas, SDM, dana dana sudah dirasa memadai dan juga sudah diwacanakan hal tersebut. Saat ini baru sekolah-sekolah yang datang karena mereka tahu dari media.

"Kendala SDM yg terbatas dalam mengelola Deltamart dan Goa Lauk" - Subyek Lukky

"Guide Goa Lauk ada jadwal, tapi belum tetap karena reward atau gaji yang kurang mencukupi, tetapi kedepan berpotensi ekonomi asal kemasan promosi bagus. Kuantitas pengelola sangat cukup, hanya kualitas yang minim, memotivasi SDM sangat penting, namun perlu didukung ekonominya, karena kebutuhan hidup" - Subyek Jaro Yayat

"Goanya hampir semua orang mengapresiasi tempat yang layak dan baik untuk dikunjungi. Kendala SDM dan pengelolaan wisata belum dikuasai, penataan masih minim, butuh bantuan, serta keterbatasan dana. Akses jalan sudah mulai rusak lagi, akses jalan jadi salah satu keluhan pengunjung. Promosi masih kurang. Visi-misi bupati Lebak yaitu mengangkat wisata-wisata lokal, harapannya wisata tumbuh berkembang akan meningkatkan ekonomi setempat" - Subyek Jaro Yayat

"Goa lauk dahulu adalah lokasi yang dianggap menakutkan oleh masyarakat, namun Pak Jaro mendesain Goa Lauk menjadi lokasi yang familiar dengan masyarakat agar mengubah kesan menakutkan yaitu dgn mebuat wahana kolam renang yg berwarna, meskipun ada sebagian warga yg mengomentari negative. Yang banyak main anak-anak sekolah olah raga berenang." - Subyek Jaro Yayat

Goa Lauk juga membuat paket seperti yang mengunjungi pantai sawarna juga bisa datang ke Goa Lauk, namun itu yang membuat adalah dari pihak pantai Sawarna, tapi kalau 
khusus Goa Lauk belum mengadakan khusus hal tersebut. Yang baru dilakukan adalah memaketkan jelajah Gua dengan Nasi Liwet. Hal ini yang dinamakan dengan Sales Promotion. Jadi sebetulnya sudah dilakukan walau masih dibilang sederhana.

"Pengunjung yg ke Ciletuh Geopark, Pelabuhan Ratu, ke Sawarna, wisata goa lauk di antara jalur wisata tersebut terkadang terlewat begitu saja. Pernah ada yang menanyakan Goa Lauk, namun ditawarkan oleh guide wisata lain." - Subyek Jaro Yayat

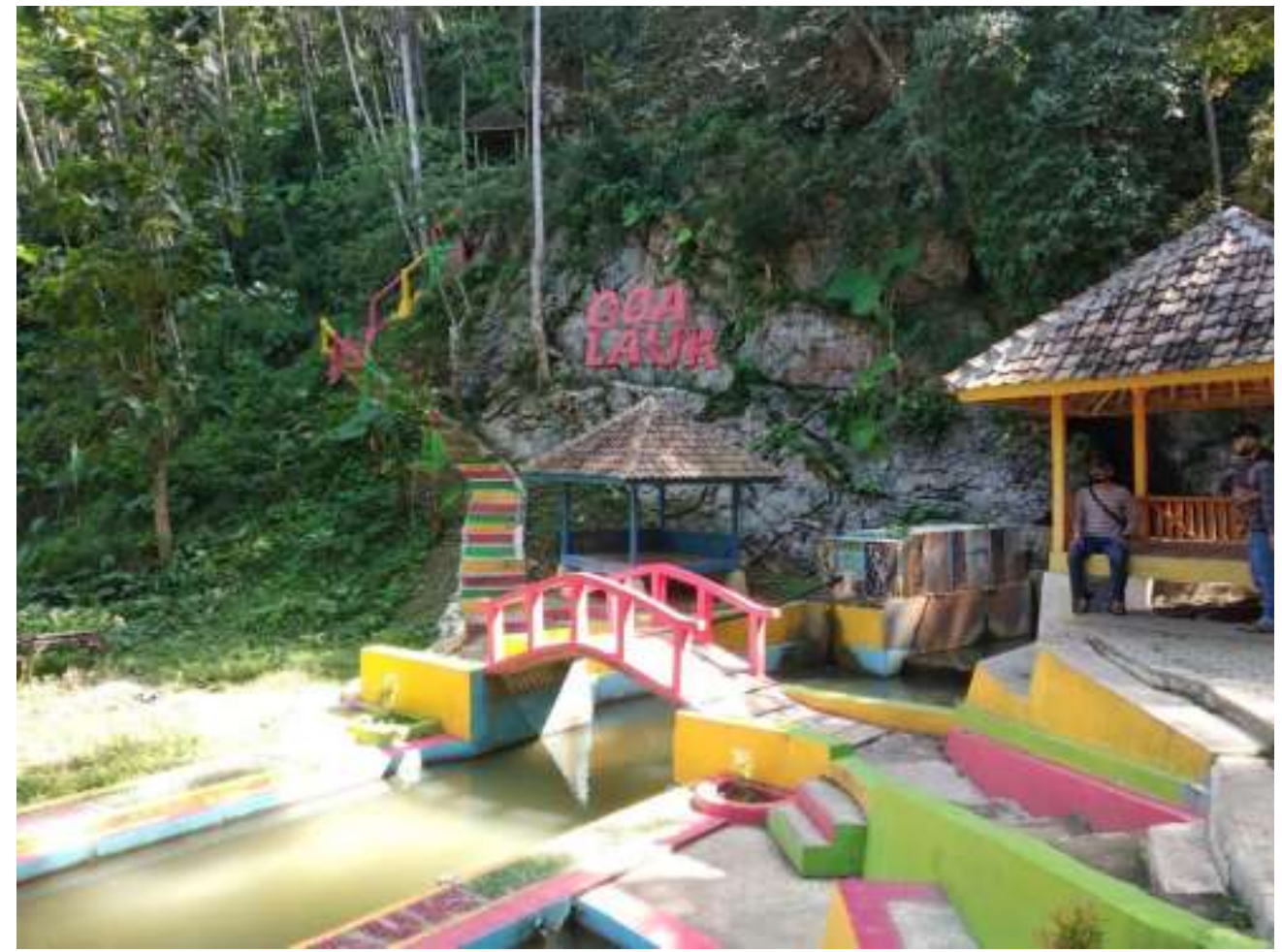

Gambar 6. Penampilan Ramah Pengunjung Wisata Goa Lauk

Goa Lauk juga membuat paket seperti yang mengunjungi pantai sawarna juga bisa datang ke Goa Lauk, namun itu yang membuat adalah dari pihak pantai Sawarna, tapi kalau khusus Goa Lauk belum mengadakan khusus hal tersebut. Yang baru dilakukan adalah memaketkan jelajah Gua dengan Nasi Liwet. Hal ini yang dinamakan dengan Sales Promotion. Jadi sebetulnya sudah dilakukan walau masih dibilang sederhana.

"Pengunjung yg ke Ciletuh Geopark, Pelabuhan Ratu, ke Sawarna, wisata goa lauk di antara jalur wisata tersebut terkadang terlewat begitu saja. Pernah ada yang menanyakan Goa Lauk, namun ditawarkan oleh guide wisata lain." - Subyek Jaro Yayat

Dariwarga sekitar memandang Goa Lauk awalnya kurang mendukung menurut Pak Yayat, lurah Desa Lebaktipar. Namun seiring dengan komunikasi yang dijalankan masyarakat berubah jadi mendukung, karena dengan dibuka jalan menuju ke Goa Lauk masayarakat juga dapat memetik hasil dengan dapat membawa hasil alam dengan lebih mudah. Bahkan sampai banyak yang memberikan tanahnya untuk dipakai secara Cuma-Cuma.

"Gotong royong cukup eksis, untuk menjaga lingkungan pola pikir masyarakat sudah mulai bergeser, contoh orang dulu punya istilah "budak ulah ulin ka dungus beusi ka kacatap" artinya anak-anak jangan main ke hutan (yang memiliki sumber air) takut celaka, jika ditelaah istilah ini mengandung makna bahwa kita harus menjaga kelestarian alam." - Subyek Jaro Yayat 
Hal ini menarik karena latar belakang masyarakat beda-beda baik dari pendidikan dan lainnya, oleh karena itu untuk melakukan pendekatan dilakukan tidak secara bersamaan, namun secara khusus, sehingga masyarakat mau mendukung. Sebagai contoh dilakukan perbedaan untuk menyampaikan kepada masyarakat dari segi bahasa, ada yang menggunakan bahasa sunda, ada yang menggunakan bahasa indonesia. Disampaikan dalam forum hajatan atau pengajian. Ke Depan juga ada rencana untuk membuka jalan lebih lebar lagi supaya dapat masuk mobil. Wisata edukasi mempunyai treatment khusus yang berbeda dari wisata pada umumnya.

\section{SIMPULAN}

Sudah banyak kegiatan komunikasi pemasaran yang dilakukan oleh pengelola Goa Lauk, namun hal tersebut belum cukup untuk mengangkat citra Goa Lauk. Pengelola menghadapi masalah utama yaitu tentang SDM dan permodalan, dimana hal tersebut sebetulnya dapat diatasi dengan alternatif-alternatif kreatif yang dapat digunakan. Goa Lauk sebetulnya mempunyai potensi besar untuk wisata karena sumber daya alam yang tidak banyak dimiliki di tempat lain, namun butuh upaya serius untuk mempromosikan hal tersebut. Kegiatan komunikasi pemasaran yang sudah dilakukan belumlah cukup, sehingga harus ditingkatkan dengan strategi zero budget marketing.

\section{DAFTAR PUSTAKA}

Dwiastuti, R., et al. (2012). IImu Perilaku Konsumen. Malang: UB Press.

Kayode, O. (2014). Marketing Communication, (1st ed.). Bookboon.

Kotler, P. \& Keller, K. L. (2009). Manajemen Pemasaran. Jakarta: Erlangga.

Muhadjir, N. (1996). Metodologi Penelitian Kualitatif. (3rd ed.). Yogyakarta: Rake Sarasin.

Rakhmat, J. (2001). Psikologi Komunikasi (Edisi Revisi). Bandung: PT Remaja Rosdakarya.

Shimp, T. A. (2003). Periklanan dan Promosi. Jakarta: Erlangga.

Sugiyono. (2013). Metode Penelitian Kuantitatif Kualitatif dan R \& D. Bandung: Alfabeta

Veerger, K.J. (1993). Realitas Sosial. Jakarta: Gramedia Pustaka Utama

West, E.L \& Turner, L.H. (2007). Introducing Communication Theory: Analysis and Application. New York: McGraw-Hill Higher Education 